\title{
PENGARUH PERUBAHAN ORGANISASI TERHADAP KINERJA PEGAWAI DI LINGKUNGAN KERJA UNIVERSITAS TEUKU UMAR
}

\author{
Fuadri $^{1)}$ \\ ${ }^{1)}$ Staf Pengajar Program Studi Teknik Industri, Fakultas Teknik Universitas Teuku Umar \\ fuadri@yahoo.com
}

\begin{abstract}
Change the status of University College Teuku Umar became the government automatically has an influence on the changing demands of the organizational structure effectively and efficiently in accordance with service needs and organizational rules that apply. Organizational changes that occur in the work environment Teuku Umar University must also be accompanied by the provision of adequate human resources and competent, thus supporting the implementation of excellent service. No employee performance has not been able to run the organization function effectively and efficiently, thus greatly affecting service performance work environment Teuku Umar University. The results of the study in this paper shows that the factors that influence employee performance environment of the University of Teuku Umar include quality of work, attitude, initiative, responsibility, mastery of work, quantity of work and labor relations. The influence of the relationship of organizational change on employee performance seen in the regression coefficient obtained is $\mathrm{Y}=0.771+0.778 \mathrm{X}$, where $\mathrm{Y}$ is the dependent variable in the form of employee performance and $\mathrm{X}$ is the independent variable or organizational change. This test also inform the level of closeness of their relationship by $67.20 \%$
\end{abstract}

Keywords : Influence, organization, employee performance

\section{PENDAHULUAN}

Organisasi merupakan perserikatan orang-orang yang usahanya harus dikoordinasikan, tersusun dari sejumlah sub sistem yang saling berhubungan dan saling tergantung, bekerja sama atas dasar pembagian kerja, peran dan wewenang serta mempunyai tujuan tertentu yang hendak dicapai. Sumber daya manusia merupakan aset organisasi yang paling penting, dan membuat sumber daya organisasi lainnya menjadi bekerja. Tanpa kehadiran sumber daya manusia di suatu organisasi ataupun perusahaan maka terasa hambar.Suatu organisasi ataupun perusahaan dapat meningkatkan kinerjanya yang berdampak pada kinerja pegawainya (Husein, 1999).

Penelitian serupa lainnya adalah yang dilakukan Suparman (2007) dengan judul Analisis pengaruh peran kepemimpinan, motivasi dan komitmen organisasi terhadap kepuasan kerja dalam meningkatkan kinerja pegawai. Berdasarkan analisis Structural Equation Modelling (SEM) diperoleh hasil bahwa peran kepemimpinan, motivasi dan komitmen organisasi berpengaruh positif dan signifikans terhadap kepuasan kerja dan kinerja pegawai.

Pasca perubahan status Universitas Teuku Umar menjadi Perguruan Tinggi Pemerintah, sangat berpengaruh terhadap tuntutan perubahan organisasi di lingkungan tersebut, terutama untuk memenuhi kebutuhan organisasi yang efektif dan efisien. Kinerja pegawai yang ada belum mampu menjalankan fungsi organisasi secara optimal, sehingga sangat mempengaruhi kinerja pelayanan dilingkungan kerja Universitas Teuku Umar. 
Penelitian ini bertujuan untuk mengetahui faktor-faktor yang mempengaruhi kinerja pegawai terhadap perubahan organisasi dilingkungan Universitas Teuku Umar, dan bagaimana pengaruh hubungan keduanya terhadap peningkatan pelayanan yang optimal.

\section{KAJIAN LITERATUR}

\subsection{Pengertian Pengembangan Organisasi}

Pengembangan Organisasi merupakan cara pendekatan terhadap perubahan yang berjangka panjang dan lebih luas ruang lingkupnya dengan tujuan untuk menggerakkan seluruh organisasi ke arah tingkat fungsional yang lebih tinggi. Makna pengembangan oraganisasi menurut beberapa ahli : (Husein, 1999)

1. Robbins, pengembangan organisasi adalah sebuah metode yang bertujuan mengubah sikap, nilai dan keyakinan dari karyawan sehingga karyawan itu sendiri dapat mengidentifikasi dan mengimplementasikan perubahan teknis seperti reorganisasi, fasilitas yang dirancang ulang dan halhal yang dibutuhkan untuk meningkatkan organisasi mereka.

2. Christine S. Becker mendefinisikan pengembangan organisasi adalah suatu proses dari perubahan berencana terhadap orang - orang yang ada yang ada dalam organisasi secara keseluruhan. Pusat perhatiannya adalah perubahan organisasi dengan meneliti orang - orang yang ada dalam organisasi tersebut, mengenai bagaimana mereka bekerja sama sebagai suatu kesatuan, bagaimana berfungsi dalam unit merek masing-masing, dan apa yang perlu diubah sehingga mereka dapat bekerja secara efektif.

3. French dan Bell, pengembangan organisasi adalah suatu usaha jangka panjag untuk memperbaiki proses-proses pemecahan masalah dan pembaharuan organisasi, terutama melalui manajemen budaya organisasi yang lebih efektif dan kolaboratif dengan tekanan khusus pada budaya tim kerja formal dengan bantuan agen perubahan (change agent), katalisator, dan pengguna teori serta teknologi ilmiah kepeilakuan terapan dan mencakup riset kegiatan.

4. Bennis, pengembangan organisasi adalah suatu tanggapan terhadap perubahan, suaru strategi komplek yang bersifat pendidikan yang dimaksudkan untuk merubah berbagai pandangan, sikap, nilai dan struktur organisasi, agar organisasi dapat menyesuaikan secara lebih baik dengan teknologi, pasar dan tantangan-tantangan baru, serta tingkat kesulitan perubahan itu sendiri.

\subsection{Teknik Pengembangan Organisasi}

Untuk melakukan pengembangan organisasi, diperlukan cara-cara atau teknik tertentu. Ada berbagai teknik yang dirancang para ahli, dengan tujuan meningkatkan kemampuan berkomunikasi serta bekerja secara efektif antar individu maupun antar kelompok dalam organisasi. Beberapa teknik yang sering digunakan berikut ini.

1. Sensitivity Training

2. Team Building

3. Survey Feedback

4. Transcational Analysis (TA)

5. Intergroup Activities

6. Process Consultation

7. $\quad$ Third-part Peacemaking

\subsection{Kinerja Pegawai}

Kinerja adalah merupakan perilaku yang nyata ditampilkan setiap orang sebagai prestasi kerja yang dihasilkan oleh karyawan sesuai dengan perannya dalam perusahaan. Sedangkan prestasi kerja adalah hasil kerja secara kualitas dan kualitas yang dicapai oleh seorang pegawai dalam melaksanakan 
tugasnya sesuai dengan tanggung jawab yang diberikan kepadanya (Handayaningrat, 1982). Kinerja juga dapat diartikan sebagai suatu keadaan yang menunjukan kemampuan seorang karyawan dalam menjalankan tugas sesuai dengan standart yang telah ditentukan oleh organisasi kepada karyawan sesuai dengan job deskriptipnya.

\subsubsection{Faktor-Faktor Yang Mempengaruhi Kinerja}

Terkait dengan faktor-faktor yang mempengaruhi kinerja, Winardi (1996) mengemukakan bahwa faktor-faktor tersebut dapat dikelompokkan menjadi dua, yaitu faktor intrinsik dan faktor ekstrinsik. Faktor intrinsik meliputi motivasi, pendidikan, kemampuan, keterampilan dan pengetahuan. Faktor ekstrinsiknya adalah lingkungan kerja, kepemimpinan, hubungan kerja dan gaji.

Faktor yang mempengaruhi pencapaian kinerja adalah faktor kemampuan (ability) dan faktor motivasi (motivation). Hal ini sesuai dengan pendapat Keith Davis (2000; dalam Manullang, 1981) yang merumuskan bahwa:

Human Performance $=$ Ability + Motivation

Motivation $=$ Attitude + Situation

Ability = Knowlage + Skill

Sejalan dengan itu, faktor-faktor yang mempengaruhi kinerja sumber daya manusia menurut Randal, (1997) meliputi:

1. Faktor internal pegawai.

2. Faktor lingkungan internal organisasi.

3. Faktor lingkungan eksternal organisasi.

Dari berbagai pendapat ahli tersebut, maka sesuai dengan tulisan ini, maka kinerja karyawan secara umum dipengaruhi oleh dua faktor utama yaitu variabel organisasi dan individual. Dari uraian di atas, dapat disimpulkan bahwa faktor-faktor yang mempengaruhi kinerja SDM pada dasarnya terdiri dari dua faktor, yaitu dari faktor internal diri karyawan seperti kemampuan, keahlian, motivasi, dan kepribadian. Kemampuan yang dimiliki oleh seorang karyawan salah satunya ditentukan kecerdasan yang dimilikinya. Faktor yang kedua adalah faktor eksternal, baik yang berasal dari internal organisiasi itu sediri seperti kepemimpinan, iklim organisasi, dan lainnya, maupun dari eksternal organisasi seperti krisis ekonomi dan inflasi.

\subsubsection{Pengukuran Kinerja}

Kinerja pada dasarnya adalah apa yang dilakukan atau tidak dilakukan karyawan. Kinerja karyawan adalah yang mempengaruhi seberapa banyak mereka memberikan kontribusi kepada organisasi yang diantara lain termasuk:

1. Kuantitas.

2. Kualitas.

3. Jangka waktu.

4. Kehadiran ditempat kerja dan sikap kooperatif.

Sedangkan menurut Wursanto (1985) ada beberapa data atau sumber pengukuran perusahaan terhadap kinerja antara lain:

1. Kualitas Pekerjaan.

2. Kejujuran Karyawan.

3. Inisiatif.

4. Kehadiran Dan Pengetahuan Tentang Pekerjaan.

5. Sikap Dan Tanggung Jawab.

6. Kerja Sama Dan Keandalan. 


\section{METODOLOGI}

Dalam penelitian ini penulis mengambil desain kausalistik sebagai media untuk membuktikan hubungan sebab akibat atau hubungan saling mempengaruhi dari variabel-variabel yang diteliti. Populasi yang digunakan adalah seluruh staf dan dosen yang bertugas di Universitas Teuku Umar. Selanjutnya untuk menentukan ukuran sampel, penulis memperhatikan empat faktor yang dipersyaratkan, yakni degree of homogenity, Pressisi yang dikehendaki, rencana analisa serta adanya perkiraan tenaga, biaya dan waktu yang akan dikeluarkan. Besarnya sampel yang akan diambil dalam penelitian ini ditentukan dengan menggunakan rumus slovin (Sofian Siregar, 2012 :149) yaitu :

$$
\begin{aligned}
& n=\frac{N}{N(e)^{2}+1} \\
& \text { Keterangan: } \mathrm{n}=\text { Sampel } \\
& \mathrm{N}=\text { Jumlah Populasi } \\
& \text { e = Perkiraan Tingkat Kesalahan (Error) }
\end{aligned}
$$

Penarikan sampel yang akan dilakukan dengan teknik sampling acak bertingkat atau cluster random sampling untuk subset populasinya.

Pengambilan data dilakukan dengan menggunakan kuesioner yang dipersiapkan, kuesioner yang digunakan dalam penelitian ini berisi dua bagian utama. Bagian yang pertama adalah tentang profil sosial dan identifikasi responden, berisi data responden yang berhubungan dengan identitas responden dan keadaan sosial seperti: usia, jabatan, pendidikan terakhir, dan masa kerja. Sedangkan bagian kedua berdasarkan konsep teori yang dikemukakan sebelumnya, menyangkut tentang faktor-faktor yang mempengaruhi kinerja. Untuk menganalisa data digunakan metode analisa kualitatif dan kuantitatif.

Pengujian hipotesis dilakukan dengan menggunakan metode analisa regresi linier sederhana dengan menggunakan persamaan $\mathrm{Y}=\mathrm{a}+\mathrm{bx}$.

\section{HASIL DAN DISKUSI}

\subsection{Analisis Interprestasi Perubahan Organisasi}

Terdapat 12 butir pertanyaan berkenaan dengan perubahan organisasi yang dijabarkan kedalam tangapan responden terhadap adanya perubahan organisasi, kontrol formal serta kompleksitas tugas seperti apakah pembagian tugasnya semakin jelas, kuantitas pekerjaan yang semakin banyak serta kompleks atau tidaknya pekerjaan. Dari hasil penghitungan yang dilakukan diketahui bahwa untuk item perubahan organisasi diperoleh nilai $87,0 \%$ menyatakan setuju dan hanya 2,2\% yang tidak setuju. Sedangkan sisanya bersifat netral. Hal ini menandakan bahwa responden sangat mendukung adanya perubahan organisasi ini karena akan meningkatkan pelayanan, pekerjaan yang dilakukan akan semakin efisien dan terjadinya hubungan kerja yang nyaman antara sesama pegawai. Sedangkan untuk kontrol formal yang terdiri dari SOP, peningkatan standar didalam bekerja, serta pengontrolan dan pengawasan yang lebih ketat oleh atasan, responden yang menjawab setuju sebanyak 84,6\% atau 67 orang, sedangkan $1,6 \%$ atau 2 orang responden menyatakan tidak setuju serta 13,9 \% responden lainnya menganggap biasa saja.

Seragam dengan dua item sebeumnya, untuk kompleksitas tugas, responden juga sangat mendukung penuh akan hal tersebut. Hal ini berarti bahwa dengan adanya perubahan organisasi maka secara tidak langsung tugas yang diemban oleh pegawai akan semakin besar pula. Dari tabel terlihat bahwa $80,6 \%$ atau 64 responden telah memahami terhadap hal tersebut dan sangat mengharapkan terjadinya kesinambungan untuk dimasa-masa yang akan datang dalam rangka mewujudkan Universitas Teuku Umar sebagai basis pendidikan Wilayah Barat Selatan Aceh. Untuk lebih jelasnya dapat dilihat pada tabel berikut. 
Tabel 1. Tabulasi Jawaban Perubahan Organisasi

\begin{tabular}{lccccc}
\hline \multicolumn{1}{c}{ Indikator } & STS & TS & N & S & SS \\
\hline Perubahan Organisasi & 0,3 & 1,9 & 10,8 & 69,3 & 17,7 \\
Kontrol Formal & 0,8 & 0,8 & 13,9 & 71,4 & 13,2 \\
Kompleksitas Tugas & - & 1,3 & 18,1 & 65,4 & 15,2 \\
\hline
\end{tabular}

Sumber: Data Primer Diolah 2015.

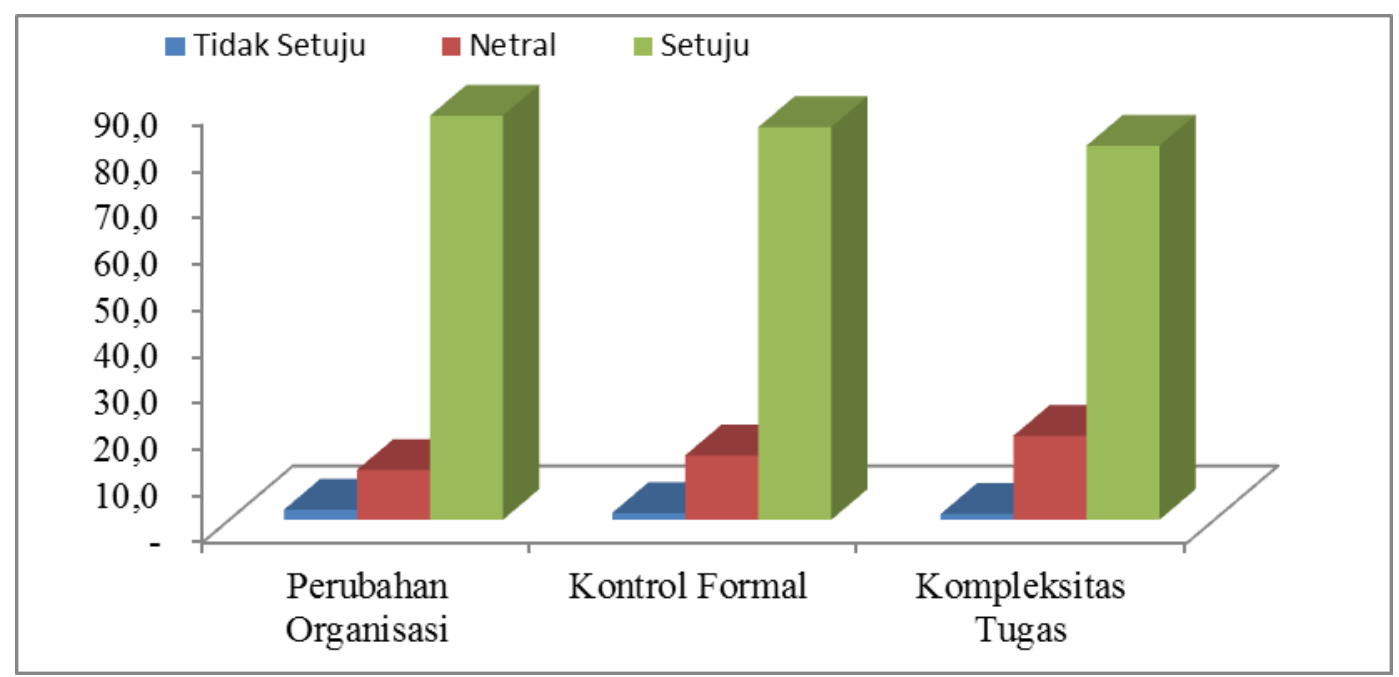

Gambar 1. Tabulasi Jawaban Responden Tentang Perubahan Organisasi

\subsection{Analisis Interprestasi Kinerja Pegawai}

Dalam analisis kinerja pegawai terdapat 24 butir pertanyaan yang terbagi kedalam 7 sub topik, yaitu kualitas pekerjaan, sikap pegawai, inisiatif, tanggung jawab, penguasaan pekerjaan, kuantitas pekerjaan dan hubungan kerja. Dari 7 sub topik tersebut, rata-rata 89,8\% responden atau sebanyak 71 orang setuju bahwa kinerja akan berbanding lurus dengan adanya perubahan organisasi, 9,3 \% responden bersikap netral dan hanya $0,9 \%$ responden yang tidak setuju adanya hubungan antara perubahan organisasi dengan kinerja.

Untuk kualitas pekerjaan, terdapat beberapa hal yang menjadi dasar pertanyaan dalam kuisioner penelitian. Hasil tabulasi diperoleh bahwa responden yang setuju terhadap peningkatan kualitas pekerjaan sebanyak $87,3 \%$ yang terdiri dari $76,6 \%$ kategori setuju dan 10,8\% sangat setuju. Sementara 10,8\% responden bersifat netral dan 1,9\% lainnya tidak setuju dengan perlunya peningkatan kualitas pekerjaan sebagaimana yang telah diterapkan oleh atasan maupun prosedur tetapnya.

Untuk sikap pegawai, sebanyak 96,2\% responden setuju untuk berusaha secara maksimal dalam melaksanakan tugas yang telah diberikan sesuai dengan tugas pokok dan fungsinya masing-masing serta mendukung seluruh kebijakan yang berkenaan dengan perubahan organisasi. Di lain pihak responden juga menyatakan kesiapannya untuk selalu meningkatkan prestasi kerja.

Dari 96,2\% tersebut, 30,8\% atau 25 responden diantaranya bahkan sangat setuju dengan kebijakan perubahan organisasi untuk peningkatan kinerja pegawai. Untuk inisiatif pegawai, tanggung jawab, penguasaan pekerjaan, kuantitas pekerjaan dan hubungan kerja semuanya menunjukkan sikap yang positif dari seluruh responden dengan nilai terkecil 86,1\% dan nilai terbesar 91,6\%, untuk lebih jelasnya dapat dilihat pada table 2 - tabel 3, gambar 2. berikut.

Tabel 2. Tabulasi Jawaban Kinerja Pegawai

\begin{tabular}{lllrrr}
\hline \multicolumn{1}{c}{ Indikator } & STS & TS & N & S & SS \\
\hline Kualitas Pekerjaan & 0,3 & 1,6 & 10,8 & 76,6 & 10,8 \\
Sikap Pegawai & 0,3 & 0,4 & 3,4 & 65,4 & 30,8
\end{tabular}




\begin{tabular}{lccccc} 
Inisiatif & 0,3 & 0,4 & 8,0 & 69,6 & 21,9 \\
Tanggung Jawab & 0,3 & - & 8,9 & 70,3 & 20,3 \\
Penguasaan Pekerjaan & 0,3 & 0,4 & 11,8 & 72,2 & 15,2 \\
Kuantitas Pekerjaan & 0,3 & 0,9 & 13,0 & 75,9 & 10,1 \\
Hubungan Kerja & 0,2 & 0,7 & 9,6 & 72,2 & 17,3 \\
\hline
\end{tabular}

Sumber: Data Primer Diolah 2015.

Tabel 3. Gambaran Jawaban Kinerja Pegawai

\begin{tabular}{lccc}
\hline \multicolumn{1}{c}{ Indikator } & Tidak Setuju & Netral & Setuju \\
\hline Kualitas Pekerjaan & 1,9 & 10,8 & 87,3 \\
Sikap Pegawai & 0,7 & 3,4 & 96,2 \\
Inisiatif & 0,7 & 8,0 & 91,6 \\
Tanggung Jawab & 0,3 & 8,9 & 90,5 \\
Penguasaan Pekerjaan & 0,7 & 11,8 & 87,3 \\
Kuantitas Pekerjaan & 1,3 & 13,0 & 86,1 \\
Hubungan Kerja & 0,9 & 9,6 & 89,5 \\
\hline
\end{tabular}

Sumber: Data Primer Diolah 2015.

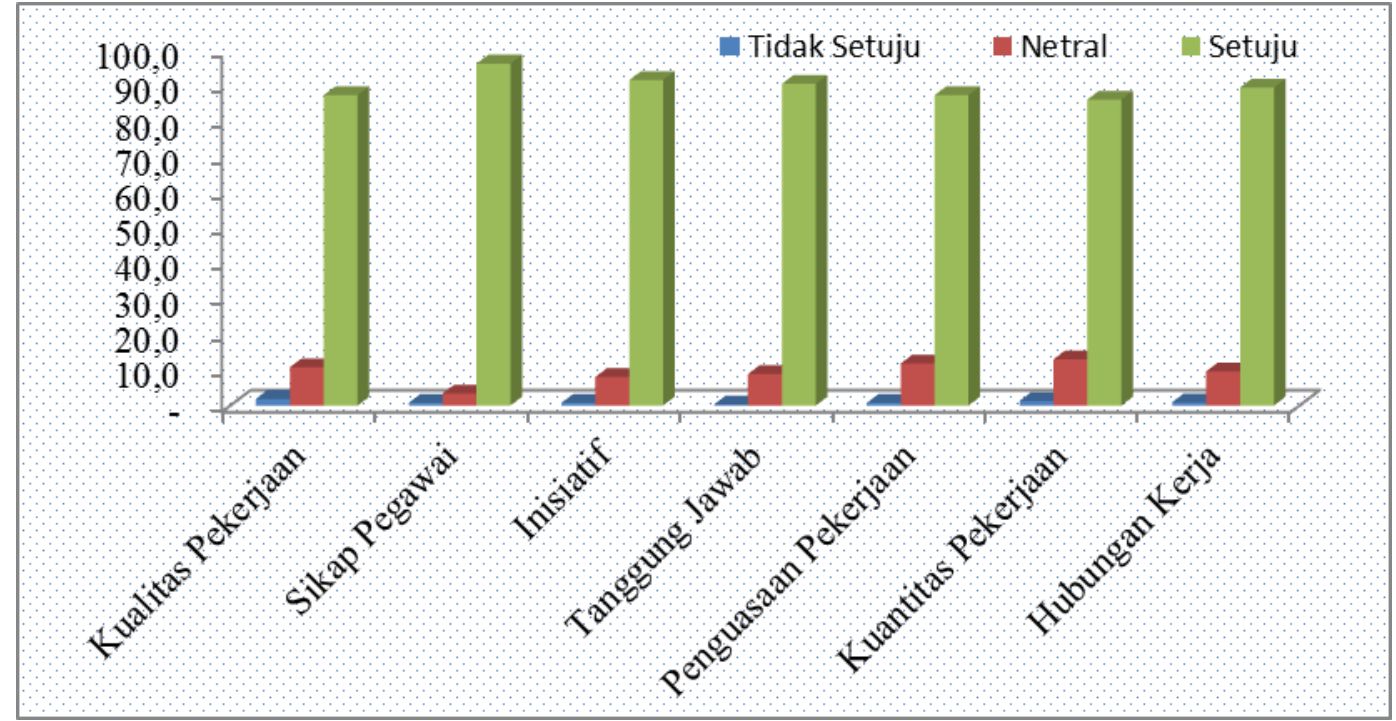

Gambar 2. Tabulasi Jawaban Responden Tentang Kinerja Pegawai

\subsection{Estimasi Model Regresi Linier}

Estimasi model dimaksudkan untuk mengetahui ketepatan model yang digunakan dalam melakukan prediksi persoalan penelitian. Dalam prediksi ini nantinya akan diperoleh persamaan yang akan dihgunakan untuk melihat hubungan antara perubahan organisasi dengan kinerja pegawai. Namun sebelum menentukan model regresi tersebut, data penelitian terlebih dahulu dilakukan uji asumsi klasik untuk memperoleh derajat kualitas data yang dapat dipertanggungjawabkan untuk melakukan analisis lanjutan dengan menggunakan tools IBM SPSS Statistics 17.

\subsection{Uji Asumsi Klasik}

\section{Multikoliniearitas}

Uji asumsi klasik multikolinieritas ini digunakan untuk mengukur tingkat keeratan pengaruh antar variabel bebas (perubahan organisasi) melalui besaran koefisien korelasi(r). Multikolinieritas terjadi jika koefisien korelasi antar variabel bebas lebih besar dari 0,60 (pendapat lain: 0,50 dan 0,90). Dilain pihak dikatakan tidak terjadi multikolinieritas jika koefisien korelasi antar variabel bebas lebih kecil atau sama dengan 0,60 $(r<0,60)$ untuk lebih jelasnya dapat dilihat pada table 4. Uji Multikoliniearitas berikut. 
Tabel 4. Uji Multikoliniearitas

Coefficients $^{\mathrm{a}}$

\begin{tabular}{|c|c|c|c|c|c|c|c|c|}
\hline & \multirow{2}{*}{ Model } & \multicolumn{2}{|c|}{$\begin{array}{l}\text { Unstandardized } \\
\text { Coefficients }\end{array}$} & \multirow{2}{*}{$\begin{array}{c}\text { Standardized } \\
\text { Coefficients } \\
\text { Beta }\end{array}$} & \multirow[t]{2}{*}{$\mathbf{t}$} & \multirow{2}{*}{ Sig. } & \multicolumn{2}{|c|}{ Collinearity Statistics } \\
\hline & & B & Std. Error & & & & Tolerance & VIF \\
\hline \multirow{2}{*}{1} & (Constant) & ,771 & ,403 & & 1,913 & ,059 & & \\
\hline & Kinerja & ,778 & ,098 & 672 & 7,966 & ,000 & 1,000 & 1,000 \\
\hline
\end{tabular}

a. Dependent Variable: Perubahan_Org

Sumber: Data Primer Diolah 2015.

Dari tabel 4. diatas dapat dilihat nilai VIF sebesar 1,00 dan nilai toleransinya sebesar 0,801. Karena nilai VIF dari kedua variabel tidak lebih besar dari 10 atau 5 maka dapat dikatakan tidak terjadi multikolinieritas pada variabel bebas (perubahan organisasi) tersebut. Berdasarkan syarat asumsi klasik regresi linier dengan OLS, maka model regresi linier yang baik adalah yang terbebas dari adanya multikolinieritas. Dengan demikian, model di atas telah terbebas dari adanya multikolinieritas.

\section{Autokorelasi}

Persamaan regresi yang baik adalah tidak memiliki masalah autokorelasi. Jika terjadi autokorelasi maka perasamaan tersebut menjadi tidak baik atau tidak layak dipakai prediksi. Ukuran dalam menentukan ada tidaknya masalah autokorelasi dengan melakukan uji Durbin-Watson (DW), dengan ketentuan sebagai berikut:

1. Terjadi autokorelasi positif jika DW di bawah $-2(\mathrm{DW}<-2)$.

2. Tidak terjadi autokorelasi jika DW berada di antara -2 dan +2 atau $-2<\mathrm{DW}+2$

Hasil uji autokorelasi penelitian ini dapat dilihat pada tabel Model Summary b. Dengan membandingkan nilai Durbin-Watson output SPSS/DW hitung dengan DW tabel dengan tingkat signifikansi (error) 5\% $(\mathrm{a}=0,05)$ diketahui $(\mathrm{k}=1 ; \mathrm{n}=79) \mathrm{dL}=1,6089$ dan $\mathrm{dU}=1,6601$. Berdasarkan DW hitung diketahui bahwa nilai DW sebesar 2,237 lebih besar dari 1,6601 dan lebih kecil dari 2,3399 yang artinya berada pada daerah tidak ada autokorelasi. Sehingga dapat disimpulkan bahwa dalam model regresi linier tidak terjadi autokorelasi.

Tabel 5. Uji Autokorelasi

\begin{tabular}{cccccc}
\multicolumn{7}{c}{ Model Summary } \\
\hline \multirow{2}{*}{ Model } & \multirow{2}{*}{$\mathrm{R}$} & $\begin{array}{c}\mathrm{R} \\
\text { Square }\end{array}$ & $\begin{array}{c}\text { Adjusted R } \\
\text { Square }\end{array}$ & $\begin{array}{c}\text { Std. Error of the } \\
\text { Estimate }\end{array}$ & $\begin{array}{c}\text { Durbin- } \\
\text { Watson }\end{array}$ \\
\hline \multirow{2}{*}{1} &, $672^{\mathrm{a}}$ &, 452 &, 445 &, 21041 & 2,237
\end{tabular}

a. Predictors: (Constant), Perubahan_Org

b. Dependent Variable: Kinerja

Sumber: Data Primer Diolah 2015.

\section{Heteroskedastisitas}

Pengujian heteroskedastisitas dilakukan dengan membuat Scatterplot (alur sebaran) antara residual dan nilai prediksi dari variabel terikat (kinerja pegawai) yang telah distandarisasi. Hasil uji heteroskedastisitas dapat dilihat pada gambarScatterplotoutput SPSS seperti pada gambar di bawah ini. 


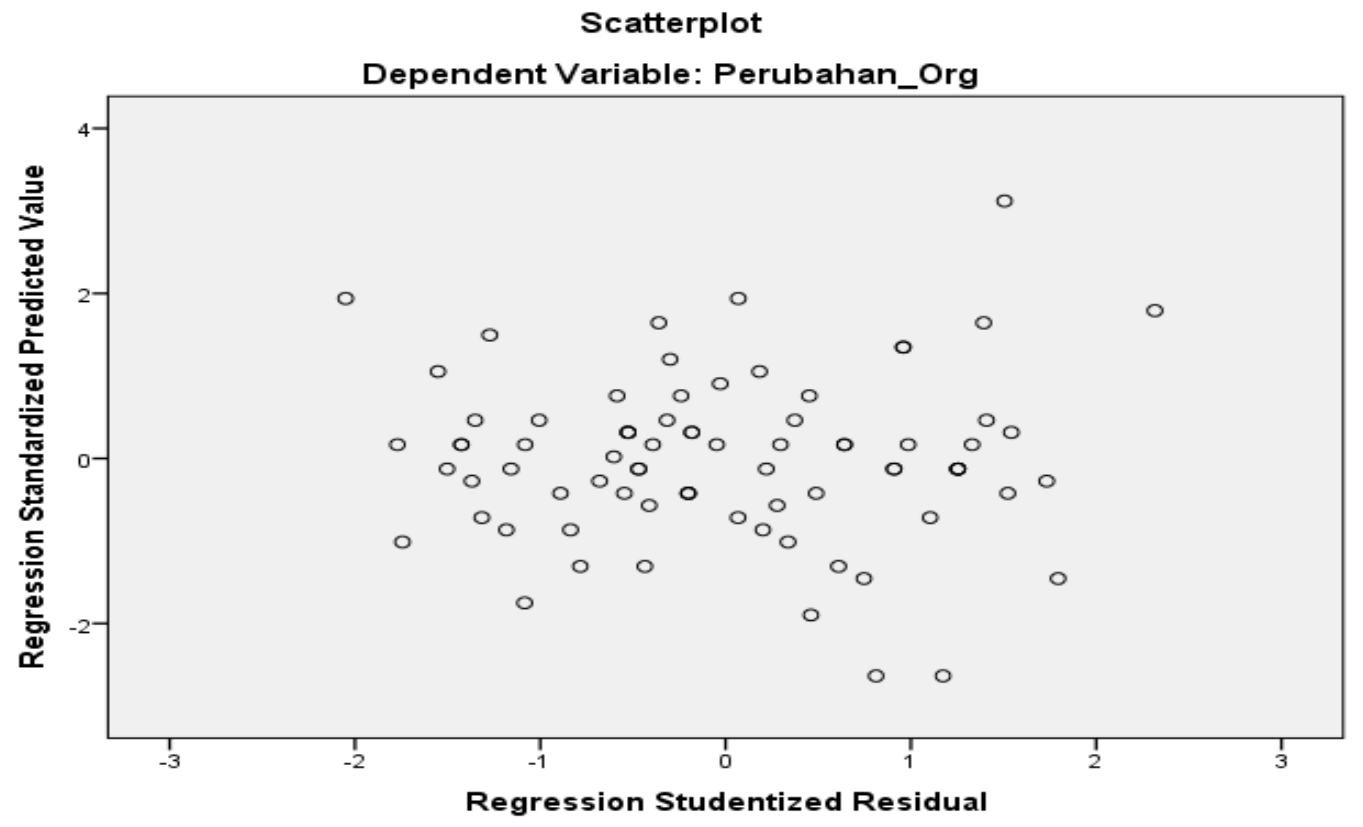

Gambar 3. Uji heteroskedastisitas

Dari gambar di atas terlihat bahwa sebaran titik tidak membentuk suatu pola tertentusehingga dapat disimpulkan tidak terjadi heteroskedastisitas. Asumsi klasik tentang heteroskedastisitas dalam model ini terpenuhi,yaitu terbebas dari heteroskedastisitas.

\section{Normalitas}

Hasil uji normalitas dapat dilihat dari gambar Normal P-P Plot hasil output SPSS yang diolah menggunakan software IBM SPSS Statistics 21.Uji normalitas ini dimaksudkan sebagai pendekatan OLSdengan data residual yang dibentuk model regresi linier terdistribusi normal.

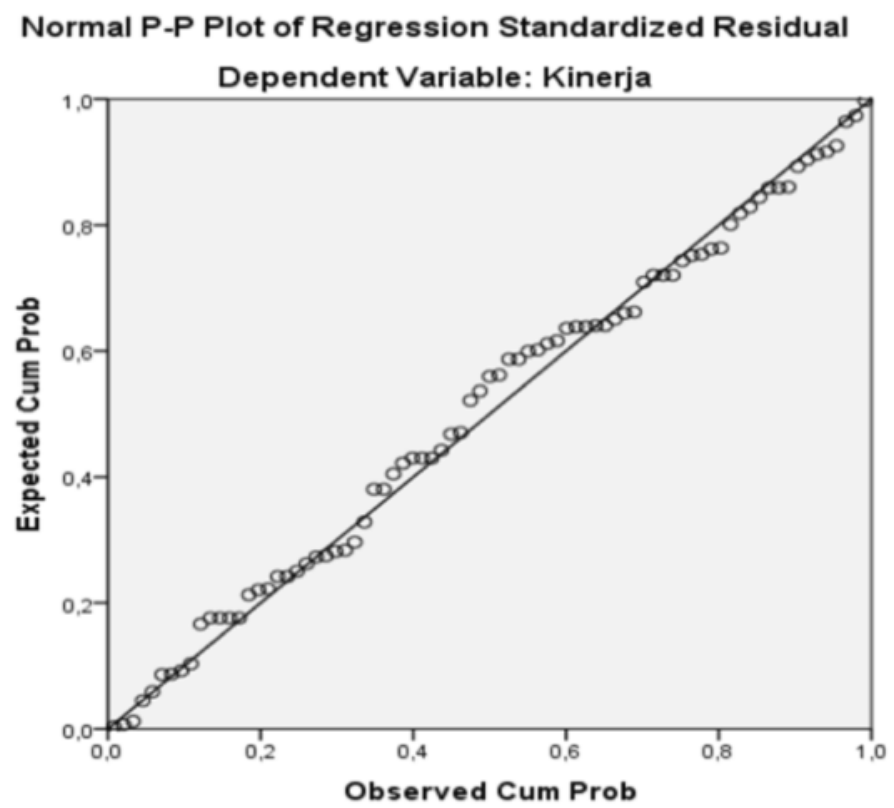

Gambar 4. Uji Normalitas 
Sebaran titik-titik dari gambar Normal P-P Plot di atas relatif mendekati garis lurus,sehingga dapat disimpulkan bahwa (data) residual terdistribusi normal. Hasil ini sejalan dengan asumsi klasik dari regresi linier dengan pendekatan OLS.

\subsection{Uji Kelayakan Model}

\section{a. Uji Kehandalan Model (Uji F)}

Uji keterandalan model atau uji kelayakan model merupakan tahapan awal mengidentifikasi model regresi yang diestimasi layak atau tidak. Layak maksudnya model yang diestimasi layak digunakan untuk menjelaskan pengaruh variabel bebas (Perubahan Organisasi) terhadap variabel terikat (kinerja Pegawai)

Dalam pengujian ini apabila nilai prob $F$ hitung lebih kecil dari tingkat error $(\alpha=0,05)$ maka dapat dikatakan bahwa model regresi yang diestimasi layak. Sebaliknya apabila nilai prob $\mathrm{F}$ hitung lebih besar dari tingkat kesalahan 0,05 maka dikatakan model regresi yang diestimasi tidak layak.Terlihat nilai sig sebesar 0,00 hal ini berarti bahwa model yang diajukan untuk menjelaskan perubahan organisasi terhadap kinerja pegawai sudah layak dan dapat dipertanggungjawabkan.

\section{Tabel 6. Uji F/Anova}

\begin{tabular}{|c|c|c|c|c|c|}
\hline \multicolumn{6}{|c|}{ ANOVA $^{a}$} \\
\hline Model & $\begin{array}{l}\text { Sum of } \\
\text { Squares }\end{array}$ & Df & $\begin{array}{l}\text { Mean } \\
\text { Square }\end{array}$ & $\mathrm{F}$ & Sig. \\
\hline 1 Regression & 2,809 & 1 & 2,809 & 63,451 &, $000^{\mathrm{b}}$ \\
\hline Residual & 3,409 & 77 & ,044 & & \\
\hline Total & 6,218 & 78 & & & \\
\hline
\end{tabular}

a. Dependent Variable: Kinerja

b. Predictors: (Constant), Perubahan_Org

Sumber: Data Primer Diolah 2015.

\section{b. Uji Koefisien Regresi (Uji t)}

Uji t dalam regresi linier dimaksudkan untuk menguji apakah parameter (koefisien regresi dan konstanta) yang diduga untuk mengestimasi persamaan/model regresi linier sudah merupakan parameter yang tepat atau belum. Maksud tepat disini adalah parameter tersebut mampu menjelaskan perilaku variabel bebas dalam mempengaruhi variabel terikatnya. Parameter yang diestimasi dalam regresi linier meliputi intersep (konstanta) dan slope (koefisien dalam persamaan linier). Pada bagian ini, uji t difokuskan hanya pada parameter slope (koefisien regresi). Hasil pengujian penelitian ini terlihat pada tabel Coefficientsaseperti pada gambar di bawah ini.

Tabel 7. Uji koefisien Regresi

\begin{tabular}{|c|c|c|c|c|c|c|c|c|}
\hline \multicolumn{9}{|c|}{ Coefficients $^{\mathrm{a}}$} \\
\hline & \multirow{2}{*}{ Model } & \multicolumn{2}{|c|}{$\begin{array}{c}\text { Unstandardized } \\
\text { Coefficients }\end{array}$} & \multirow{2}{*}{$\begin{array}{c}\text { Standardized } \\
\text { Coefficients } \\
\text { Beta }\end{array}$} & \multirow[b]{2}{*}{$\mathbf{t}$} & \multirow{2}{*}{ Sig. } & \multicolumn{2}{|c|}{$\begin{array}{c}\text { Collinearity } \\
\text { Statistics }\end{array}$} \\
\hline & & B & $\begin{array}{l}\text { Std. } \\
\text { Error }\end{array}$ & & & & Tolerance & VIF \\
\hline \multirow{2}{*}{1} & (Constant) & ,771 & ,403 & & 1,913 & ,059 & & \\
\hline & Kinerja & ,778 & 098 & 672 & 7,966 & ,000 & 1,000 & 1,000 \\
\hline
\end{tabular}

a. Dependent Variable: Perubahan_Org

Sumber: Data Primer Diolah 2015. 
Berdasarkan tabel 7 diatas menunjukan bahwa sama halnya dengan uji $\mathrm{F}$ yang telah dibahas sebelumnya pada tabel 6 , berdasarkan nilai probabilitas t yang lebih kecil dari $\alpha=5 \%$ dapat disimpulkan bahwa koefisien yang diajukan telah tepat dan dapat dipergunakan.

c. Koefisien Determinasi

Koefisien determinasi menjelaskan variasi pengaruh variabel-variabel bebas terhadap variabel terikatnya. Nilai koefisien determinasi dapat diukur dari R square. Hasil perhitungan diketahui bahwa nilai $\mathrm{R}$ Square sebesar 0,452 . Hal ini menunjukkan proporsi pengaruh variabel perubahan organisasi terhadap kinerja pegawai sebesar 45,20 \% sedangkan sisanya dipengaruhi oleh variabel lain yang tidak dijelaskan dalam model regresi linier ini. Sementara kedua variabel tersebut memiliki hubungan yang positif, yaitu sebesar $67,20 \%$.

Tabel 8. Uji Koefisien Regresi

\begin{tabular}{cccccc}
\hline Model & $\mathbf{R}$ & $\begin{array}{c}\mathbf{R} \\
\text { Square }\end{array}$ & $\begin{array}{c}\text { Adjusted R } \\
\text { Square }\end{array}$ & $\begin{array}{c}\text { Std. Error of the } \\
\text { Estimate }\end{array}$ & Durbin-Watson \\
\hline 1 &, $672^{\mathrm{a}}$ &, 452 &, 445 &, 21041 & 2,237 \\
\hline
\end{tabular}

a. Predictors: (Constant), Perubahan_Org

b. Dependent Variable: Kinerja

d. Interpretasi Model

Koefisien regresi hubungan perubahan organisasi terhadap kinerja pegawai dengannilairegresinyasebagaiberikut.

$$
Y=0,771+0,778 x
$$

Keterangan: $\quad \mathrm{Y}=$ Kinerja Pegawai

$\mathrm{X}=$ Perubahan Organisasi

Berdasarkan dari persamaam diatas terlihat bahwa arah terjadinya perubahan organisasi pada Universitas Teuku Umar bernilai positif terhadap kinerja pegawainya. Dengan perkataan lain perubahan organisasi memberikan dampak yang signifikan bagi peningkatan loyalitas pegawai dalam memberikan pelayanan dan lain sebagainya.

\section{KESIMPULAN}

Berdasarkan hasil penelitian dan analisa pada tulisan ini dapat disimpulkan bahwa faktor-faktor yang mempengaruhi kinerja pegawai di lingkup Universitas Teuku Umar meliputi: kualitas pekerjaan, sikap pegawai, inisiatif, tanggung jawab, penguasaan pekerjaan, kuantitas pekerjaan dan hubungan kerja. Faktor-faktor tersebut telah sesuai dan signifikan dalam menjelaskan hubungan perubahan organisasi terhadap kinerja pegawainya dengan hitungan kepercayaan 5\%. Nilai koefisien regresi yang diperoleh yaitu $\mathrm{Y}=0,771+0,778 \mathrm{X}$, dimana $\mathrm{Y}$ merupakan variabel terikat berupa kinerja pegawai dan $\mathrm{X}$ merupakan variabel bebas atau perubahan organisasi. Uji ini juga menginformasikan tingkat keeratan hubungan keduanya sebesar $67,20 \%$.

\section{DAFTAR PUSTAKA}

Handayaningrat Soewarno, 1982, Manajemen Kepegawaian di Indonesia, Ghalia Indonesia, Jakarta.

Husein Umar, 1999, Riset Sumber Daya Manusia dalam Organisasi. PT. Gramedia Pustaka Utama Jakarta.

Manullang,M.Drs, 1981. Manajemen Personalia. PD.Aksara Baru; Jakarta. 
Randal, S., Schuler, 1997, Manajemen Sumber Daya Manusia. Edisi ke Enam, Jilid I, Erlangga, Jakarta.

Soekidjo Notoatmodjo, 1981, Pengembangan Sumber Daya Manusia, PT. Rineka Cipta, Jakarta.

Wursanto, I.G., 1985, Dasar-dasar Manajmen Personalia, Pustaka Dian, Jakarta.

Winardi, 1981, Azaz-azaz Manajemen, Alumni, Bandung. 